\title{
Entre ossos e cientistas: um mergulho na pré-história americana
}

\section{Between bones and scientists: an exploration of American pre-history}

\author{
Ricardo Ventura Santos \\ Pesquisador titular da Escola Nacional de Saúde Pública/Fundação Oswaldo Cruz; \\ professor associado do Museu Nacional/ Universidade Federal do Rio de Janeiro \\ santos@ensp.fiocruz.br \\ Verlan Valle Gaspar Neto \\ Doutorando em Antropologia Social/Universidade Federal Fluminense \\ verlan02@yahoo.com.br
}

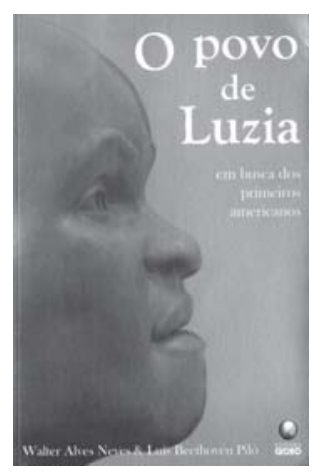

Neves, Waler Alves; Piló, Luís Beethoven. $O$ povo de Luzia: em busca dos primeiros americanos. São Paulo: Globo, 2008. 336p.
$\mathrm{U}$ m de nós conheceu Walter Neves na década de 1980, quando ele, em início de carreira, ministrou um curso sobre evolução biológica humana para estudantes de graduação em biologia na Universidade de Brasília. O outro teve o primeiro contato com ele sob condições semelhantes, porém muito mais recentemente, por ocasião de uma palestra na Universidade Federal de Juiz de Fora, em 2006, também sobre paleoantropologia. Nesses mais de vinte anos entre os dois eventos, o interesse de Neves permaneceu essencialmente o mesmo: os estudos evolutivos humanos. O que mudou foi que, se no início de sua carreira abordava basicamente, em suas aulas e palestras, pesquisas de terceiros, ao longo do tempo ele próprio se tornou um produtor de conhecimento na área, com foco no povoamento do continente americano pelas primeiras levas de Homo sapiens que aqui chegaram há milhares de anos. O povo de Luzia, escrito em parceria com o geógrafo Luís Piló, é um relato das pesquisas

que Neves vem conduzindo desde o fim dos anos 1980 e que se tornaram referências importantes no debate científico sobre o povoamento pré-histórico das Américas.

O nome de mulher (Luzia), no título do livro, se refere a um crânio escavado na década de 1970 na região de Lagoa Santa, em Minas Gerais. É uma peça do acervo do Setor de Antropologia Biológica do Museu Nacional, no Rio de Janeiro. A importância desse material reside em sua antiguidade, já que ele apresenta a mais antiga datação feita a partir de material ósseo humano em todo o continente americano, entre 11 e 11,5 mil anos. Luzia, nome inspirado no famoso fóssil africano Lucy (Australopithecus afarensis), por sua vez um dos mais antigos da linhagem evolutiva humana (aproximadamente três milhões de anos), é um espécime-chave na proposição teórica de Neves sobre as primeiras levas de humanos que chegaram às Américas. Sua proposta explicativa se contrapõe ao modelo Clovis nominado em alusão a importante sítio arquelógico nos Estados Unidos - e sustenta que, antes da migração dos ancestrais dos atuais povos indígenas (ou ameríndios), houve uma ocupação do continente por uma população morfologicamente diferenciada, que não 
apresentava uma morfologia 'mongolizada'. Ou seja, para Neves, teria havido uma leva migratória anterior àquela usualmente reconhecida pelos modelos arqueológicos e bioantropológicos mais tradicionais. Essas populações apresentariam características físicas mais próximas dos primeiros humanos que, oriundos da África, ocuparam inicialmente o sul/sudeste da Ásia e a Austrália. Teriam entrado no continente americano há aproximadamente 14 mil anos, através do estreito de Bering, localizado entre o noroeste da América do Norte (região do Alasca) e o nordeste da Ásia (Sibéria), sendo Luzia representativa dessa população.

O povo de Luzia: em busca dos primeiros americanos é um livro dirigido ao grande público. Escrito em linguagem acessível e repleto de ilustrações, é em larga medida um relato das pesquisas de Neves e colaboradores com vistas a comprovar o que denominam "modelo dos dois componentes biológicos principais" (p.155). Pode ser visto como parte de uma tradição relativamente comum nos estudos de evolução humana, que é aquela dos descobridores de importantes fósseis escreverem obras que, além de inserir (ou contrapor) seus achados nos modelos científicos vigentes, trazem relatos de cunho pessoal sobre a atmosfera no entorno da produção do conhecimento sobre as origens primevas da espécie humana.

O livro de Neves e Piló é composto por oito capítulos. Nos dois primeiros os autores apresentam, apoiados na teoria evolutiva, um panorama dos conhecimentos sobre paleoantropologia relativa aos últimos sete milhões de anos. Oferecem aos leitores um resumo das informações reveladoras de que a maior parte da evolução biológica humana aconteceu no continente africano, tendo ali se originado também o Homo sapiens anatomicamente moderno, há aproximadamente 200 mil anos atrás. O modelo, conhecido como out of Africa ou da monogênese africana, defende que a saída definitiva do sapiens moderno daquele continente, e que resultou na colonização de praticamente todo o mundo, deve ter acontecido há 45 mil anos, com a entrada nas Américas entre dez a 15 mil anos. Esses dois primeiros capítulos, além das evidências arqueológicas, bioantropológicas, moleculares e linguísticas, inserem as pesquisas de Neves e colaboradores nos debates mais amplos sobre origens e expansão do sapiens moderno.

O capítulo 3 oferece o contexto histórico das pesquisas paleontológicas e arqueológicas em um conjunto específico de sítios localizados em Lagoa Santa. Em particular, recupera o trabalho do naturalista dinarmaquês Peter Lund, na primeira metade do século XIX. Como indica o próprio título do capítulo, "De arraial no fim do mundo a centro da pré-história americana", Neves e Piló, em ricas páginas de história da ciência, mostram como as pesquisas de Lund nas grutas mineiras, inicialmente inspiradas no catastrofismo do naturalista francês Georges Cuvier, constituíram capítulo fundamental da paleontologia mundial no século XIX. Os autores detalham também as pesquisas realizadas em Lagoa Santa durante o século XX, por vários arqueólogos e paleontólogos brasileiros e estrangeiros.

No capítulo 4 são apresentados os procedimentos científicos utilizados contemporaneamente nos estudos dos materiais ósseos, em particular crânios (inclusive com foco em Luzia). Nele é mostrado como, através de uma combinação de osteometria e análise estatística multivariada, têm sido gerados os dados que sustentam os novos modelos de povoamento. Esses modelos se contrapõem àqueles derivados de estudos filogenéticos que se apoiam no estudo da variabilidade do DNA de populações indígenas contemporâneas. 
O capítulo 5 é, essencialmente, uma caracterização do ambiente físico/geográfico da região de Lagoa Santa e serve de base para as informações apresentadas nos capítulos finais. Os capítulos 6 e 7, por sua vez, detalham como as pesquisas realizadas contemporaneamente em Lagoa Santa, coordenadas por Neves, abrem janelas para compreender "como era e vivia o povo de Luzia". Finalmente, o capítulo oitavo apresenta o que os autores consideram como questões e perspectivas futuras de investigação, nos sítios arqueológicos de Lagoa Santa.

Como já referido, o livro é sobretudo um texto de divulgação científica, trazendo uma riqueza de informações e interpretações nos campos da arqueologia e da antropologia biológica sobre o povoamento do continente americano, a partir de pesquisas conduzidas no Brasil e na região de Lagoa Santa em particular. Não obstante, é também um texto de interesse para especialistas em história e antropologia da ciência. Neste caso, vale mencionar questões ligadas à produção do conhecimento científico e às relações entre centro e periferia. Há um paradigma estabelecido sobre o povoamento da América (o modelo Clóvis ou Clovis first) que, produzido, sobretudo no contexto acadêmico norte-americano e ali tendo sua principal fonte de reprodução, propõe uma data-limite de entrada da espécie humana nas Américas de 11,5 mil anos. Neves e Piló se colocam como pesquisadores que, vivendo e atuando fora do centro de produção acadêmica na área, precisam produzir uma ciência suficientemente robusta para, da periferia, derrubar paradigmas solidamente estabelecidos. Em suas próprias palavras, eles se contrapõem a um modelo explicativo que "tem sido imposto de forma mais ou menos unilateral por profissionais da América do Norte para todo o continente", ainda que "vestígios arqueológicos encontrados principalmente na América do Sul não necessariamente coincidam com as expectativas do modelo Clovis" (p.67).

Quem conhece pessoalmente Walter Neves quase consegue ouvir sua voz, ao ler várias passagens do livro. Seu estilo eloquente e enfático se faz presente não somente nas críticas ao que chega a denominar "o estrago causado pelo dogmatismo norte-americano sobre o assunto" (p.16), mas remete-se também à arqueologia brasileira, que qualifica "ingênua e romântica", além de frágil do ponto de vista teórico-metodológico, encarnando, na sua visão, "a receita perfeita para a falta de êxito" (p.72-73).

O livro oferece várias outras pistas interessantes de trabalhos que, para além da antropologia biológica e arqueologia, podem vir a ser realizados sobre Luzia. O jornalista Marcelo Leite escreve, na apresentação do trabalho, que "todo país precisa de ícones populares para apoiar a construção de sua própria identidade, para o bem ou para o mal". Os próprios autores, ao escreverem que "finalmente, a pré-história brasileira passou a ter um ícone próprio, tão importante quanto o Neandertal na Alemanha, o homem de CroMagnon na França e Lucy na Etiópia" (p.13-14), mostram-se cientes da circulação e mediação, simbólica inclusive, que Luzia pode desempenhar entre os mundos científico e leigo. Em uma linha que parece ecoar a perspectiva de 'invenção da tradição', do historiador Eric Hobsbawm, abre-se um horizonte analítico potencial que pode vir a ser explorado a partir de arcabouços teóricos e metodológicos da história e das ciências sociais. De fato, mesmo uma consulta rápida à internet permite constatar a circulação de uma diversificada iconografia associada à Luzia. Vale lembrar que nos idos de 1999-2000 esse crânio se tornou uma peça midiática, com direito a presença na capa de revistas de notícias semanais (como 
a Veja, que estampou uma matéria com o título "Luzia, a primeira brasileira"), além de ter sido abordada em documentários de divulgação científica.

Ao finalizar a leitura do livro, chega-se à conclusão de que teria sido impossível a sua publicação no país, alguns anos atrás. Certamente a persistência e a capacidade de trabalho de Walter Neves ajudaram a tornar o povoamento pré-histórico do continente americano um tema relevante na agenda de pesquisa internacional. E já é possível produzir uma síntese sobre os primeiros habitantes do território atualmente chamado Brasil, ainda que, como reconhecem os autores, muito precise ser feito para um conhecimento nuançado do tema.

O povo de Luzia não é somente instigante por seu valioso conteúdo científico. Não menos interessante é perscrutá-lo como uma narrativa dos pesquisadores a respeito de sua autoimagem de "cientistas do terceiro mundo" (p.13), de como veem a si próprios no complexo processo de produção do conhecimento em paleoantropologia, tendo como pano de fundo, além das teorias e métodos científicos, contextos históricos e socioculturais fortemente estruturados ao longo do eixo Norte-Sul.

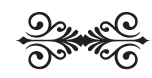

